\title{
Co(n)tidianos: um cuidado das narrativas
}

\author{
Every day tales: a care of narratives
}

\author{
Jéssica Fernandes Pinto; Michele de Freitas Faria de Vasconcelos \\ Universidade Federal de Sergipe
}

\section{RESUMO:}

A partir de tremores consequentes de encontros cotidianos, o presente artigo ensaia uma político-ética da narratividade interessada nas miudezas e delicadezas dos restos, dos rastros de vida ordinária a contradizer memórias e narrativas oficiais. Em agenciamento com a dimensão artística intrínseca a toda forma de produção e atividade humana, inventamos, pela pesquisa e pela escrita, "contidianos". Nesse texto, desdobramento de pesquisa de mestrado, trazemos um desses contos que tem como mote o costume condenável do uso de drogas, tracejando a história de uma personagem que atualiza a experiência de muitos. A aposta: o cotidiano como território de germinação e afirmação da vida e, assim, de produção de saúde. Entendendo que não há outro mundo, mas outros modos de existir, o caminho foi o de produzir sentidos provisórios e precários, narrar-se para transmutar.

Palavras-chave: saúde mental; cotidiano; narrativa; uso de drogas.

\section{ABSTRACT:}

Based on tremors as consequences of daily encounters, this article tries to introduce a political ethics of narrativity interested in the details and delicacies of the remains, of the traces of the ordinary life, to contradict the official memories and narratives. In correlation with the artistic dimension, intrinsic to every form of human production and activity, we invented, through research and writing, stories of "everyday life". In the present text, result of a master's thesis, we bring one of these stories whose main theme is the condemnable habit of drug use, tracing the steps of a character who involves the experience of many. The bet: everyday life as a territory of germination and life-affirmation and, thus, a territory of healthcare production. Having in mind that there is no other world, but other ways of existing, the path was to produce provisional and precarious senses, and to narrate oneself to transmute.

Key-words: mental health; every day life; narrative; drugs use.

DOI: 10.12957/mnemosine.2020.57659

\section{O 'causo' de uma pesquisa. Uma pesquisa que se fez 'causo'}

Caminhando pela rua de casa, em frente à portaria de um prédio, ouço ${ }^{1}$ a seguinte frase de um diálogo: “hoje vai ter uma quebradeira lá na Fonte Nova”. Imediatamente esboço um 
sorriso no rosto, vamos explicar o porquê. No final de semana anterior, houve um grande evento neste mesmo local para celebrar a canonização da primeira santa brasileira, um dia inteiro de reza e comoção. Exatamente uma semana depois iria rolar uma "quebradeira" no mesmo lugar, uma festa com músicas para quebrar, ou seja, para soltar o quadril dançando muito. A existência de movimentos opostos de contenção e soltura do corpo presentes no mesmo lugar nos encanta. Esses movimentos parecem evidenciar uma característica do que é viver o urbano: a possibilidade de existência da diferença, embora existam movimentos de homogeneização. Está aí uma característica fundamental do cotidiano: ele se diferencia. "Repetir, repetir - até ficar diferente. Repetir é um dom do estilo" (BARROS, 2014: 276).

É a partir de encontros cotidianos que essa escrita vai tomando o seu rumo. A partir do encontro com o ordinário que promove uma alteração no movimento dos músculos faciais, bem como faz estremecer todo o corpo. Em especial, a partir de um trabalho realizado em um CAPS AD III no município de $A_{r a c a j u}{ }^{2}$, onde foi possível entrar em contato com o cotidiano de pessoas que, a partir de uma insubordinação, fazem da vida uma criação, no fio da navalha entre o mortífero e o embrionário (PELBART, 2004). Ainda que rotuladas, marcadas de cicatrizes, a luta pela vida vivida é visível. Uma luta fiada pela vitalização da vida, vida como experiência de criação, ensaios de formas de ver e de se estar no mundo. As páginas que virão em seguida serão para lhes contar um 'causo' que, de tão “irrelevante”, é de uma importância não quantificável. É que, aqui, nós falamos de vida de gente que não está muito nos conformes.

A fim de fazer da própria escrita também uma experiência, a discussão dará o seu contorno a partir da narrativa do vivido, da memória e da fantasia (seria possível alguma escrita fugir disso?). Seguimos inspiradas em uma política da narratividade (PASSOS; BARROS, 2015) cujo entendimento perpassa pelo uso da língua como um posicionamento político, bem como pelo entendimento de que os modos de narrativa são produtores e produção de processos de subjetivação, constituindo experiências de si na relação com o outro. Aqui há "uma inseparabilidade entre o modo de fazer e o modo de dizer" (PASSOS; BARROS, 2015: 156). Nesses termos, se, como aponta Deleuze (1997: 55 e 56), a linguagem é um mapa político, "um sistema de comando", em alguma medida, o que intentamos é disputar narrativas, traçar outras rotas, acompanhar a germinação de sentidos outros, outrar a linguagem, infantilando-a, lembrando com Agamben (2005) que a infância é a experiência limite na e da linguagem.

O material-base para todos os escritos que aqui seguem foram diários de bordo, experiências de vida (im)pessoal e de saúde pública (como se fosse possível separar!). Entendemos aqui que não há neutralidade neste processo e que o modo de contar/relatar/dizer também é produzir dados. A narrativa propõe-se aqui a germinar por meio de um causo-conto. 
O 'causo' aqui chamado de “Aos costumes condenáveis" 3 " tem como proposta trazer um bocadinho dos encontros de uma e de várias vidas rotuladas e carimbadas como "usuários de drogas”, bem como aponta reflexões acerca dos modos de atuação clínica na saúde mental.

\section{Sem arte, morre-se de realidade}

Outro dia, uns amigos falavam sobre memes ${ }^{4}$ e fiz um comentário de que eu não tinha paciência para isto. Imediatamente um deles me perguntou “como você aguenta a realidade?". Fiquei com esta questão latejante. Em outro momento, eu estava automaticamente deslizando o meu dedo pela tela do celular enquanto aguardava em uma fila de espera. Estava visualizando os feeds sem fim quando apareceu uma imagem com a seguinte frase escrita: "sem arte morrese de realidade". Achei a reposta para meus amigos.

Não somos artistas, mas, para nós que escrevemos esse texto e que nos atrevemos a pesquisar na imanência do vivo e do viver, a arte se apresenta como a possibilidade de respiro. Não necessariamente a obra de arte, a perfeição alcançada pela repetição de uma técnica. Muito mais a arte de coexistência de mundos aparentemente paradoxais - como a reza e a quebradeira -, de criar quando nada parece ser tudo, de movimentar-se quando a ordem é de parada. A pergunta que nos acompanha, então, é: como fazer da vida uma artistagem? (CORAZZA, 2006).

$\mathrm{Na}$ tentativa de ter alguma intimidade com a artistagem da vida e de entender a relevância disso para uma escrita acadêmica, encontramos na cartografia uma "estratégia investigativa" (PASSOS; KASTRUP, 2013: 392) como inspiração. A cartografia que tem o corpo como extensão da pesquisa, em que todo ele se faz presença no ato da pesquisa, uma atenção difusa que para quando algo ressalta aos sentidos, uma atenção de corpo inteiro, um pensar com os pés no chão. Uma busca de encontro ao outro, eu e outros, tantos mundos (im)possíveis. Um fazer sentido ao longo de um processo coletivo.

Estamos atentas, então, ao que chamamos de cotidiano porque "ele escapa. Ele pertence à insignificância, e o insignificante é sem verdade, sem realidade, sem segredo, mas é talvez também o lugar de toda significação possível” (BLANCHOT, 2007: 237). Para quantificar vida de gente desgovernada, só fazendo dela um objeto; da experiência, um experimento; da história, um universal. E quando pensamos nisso, fazemos logo uma cara de quem chupou limão azedo. Por isso aqui daremos certa prioridade a uma narrativa, "porque ela trata daquilo que não pode ser verificado, daquilo que não pode ser objeto de uma constatação ou de um relato" (BLANCHOT, 2005: 271). 
Procuramos vários jeitos de dizer que todo dia não é sempre igual. Podemos morar no mesmo lugar, ir para o mesmo trabalho, bater ponto no mesmo aparelho, voltar para casa no mesmo horário, assistir o mesmo programa todas as noites e deitar à espera do despertador no dia seguinte. Contudo, nesse itinerário, todos os dias, algo diferente irá acontecer, não necessariamente agora, todos os dias amanhecemos, entardecemos e anoitecemos diferentes. "Os fatos maiores ou menores do dia a dia se transmitem por heterogêneas formas de narrar, traduções ausentes de qualquer repouso ou segurança. Porosa e vulnerável, a memória transgride ao criar infinitas possibilidades de contar o agora ou o ontem, desprezando a estabilidade dos coletivos ou das individualidades tecidas na solidão" (BAPTISTA, 2010: 28).

A repetição é acompanhada de atos de criação, sejam eles mais sutis ou mais pomposos. Essa criação, ainda que miudinha, é a vida acontecimentalizando, se apresentando, é a arte de existir se manifestando. E se a vida acontece, é preciso deixar isso em evidência. Não num sentido iluminista de descortinar uma verdade pré-existente, mas em um sentido de podermos construir juntas um impossível possível; criarmos pequenos novos caminhos; analisarmos o pessoal - que também é político - e sermos capazes de resistir com cuidado e saúde produzidos nesses encontros diários, nesses encontros que, às vezes, de tanto olharmos, nem enxergamos. "O cotidiano é aquilo que não vemos nunca uma primeira vez, mas que só podemos rever" (BLANCHOT, 2007: 237).

Aproximamo-nos, pois, aqui desta defesa do cotidiano como o território da transmutação, "um território onde vida e arte se entrelaçam. Não interessa mais precisar onde inicia ou acaba uma ou outra, mas sim o que acontece entre" (ANGELI; FONSECA, 2012: 114). Um conjunto de práticas que está intimamente vinculado às formas do discurso, ou da enunciação. "Trata-se, então, de problematizar o modo como colocamos juntas as palavras e as coisas, a linguagem e o mundo, o inteligível e o sensível, o sentido e a experiência. Por isso nossa forma de nos situarmos na relação ou no interstício entre o real e a linguagem é, literalmente, vital. Essa, e não outra, é a questão do relato e do ensaio como linguagens da experiência" (LARROSA, 2014: 112).

Para acompanhar processos de (des)subjetivação perscrutando o cotidiano entendido como território afeito à experiência, ao acontecer da vida, à criação, as narrativas são as ferramentas primordiais para a reprodução e produção destas práticas, e não só, as narrativas já são as práticas em si.

\section{Aos costumes condenáveis}


Toda a estória se quer fingir verdade. Mas a palavra é um fumo, leve demais para se prender na vigente realidade. Toda verdade aspira ser estória. Os factos sonham ser palavra, perfumes fugindo do mundo. Se verá neste caso que só na mentira do encantamento a verdade se casa à estória (COUTO, 1994: 67).

Não entendo muito de nomes, só sei que o dele vinha de longe. Há quem diga que se cavucar bem o chão - um movimento parecido com o meu ao ver uma tigela de comida na frente - é possível chegar ao outro lado do mundo. Era do nome desse outro lugar que o chamavam, da terra que está aos nossos pés, do país de cabeça para baixo. Parecia ser de cabeça para baixo, também, a sua vida. Sem casa, sem família, sem dentes, sem esperança. Sua cama era o chão, seu teto as estrelas. $\mathrm{O}$ dia que ele chegou a este mundo não se sabe, nem ele, nem a desavisada mãe. Documentos não havia e a memória estava carcomida. Nem só de falta era marcada a sua vida, algumas vezes por semana ele tinha lanche e almoço, um teto durante algumas horas, chuveiro para tomar banho, torneira para lavar roupa, a possibilidade de dormir com os dois olhos fechados ${ }^{5}$ e pessoas com quem, aos poucos, foi constituindo vínculos. ZzZzzz (ronco).

Na tentativa de buscar cuidados em saúde, chegou aqui em casa certa manhã, uááááh! (bocejo), enquanto eu dormia de barriga para cima e pescoço torto. Estava com cara de quem não dormia há tempos. Blusa branca, short marrom e um chinelo de dedo, todos manchados de tinta. Carregava consigo um charme ao prender seu cabelo encaracolado preto como jabuticaba. Tinha a pele queimada de sol e às vezes deixava aparecer suas marcas de blusa, cicatrizes e tatuagens ao realizar algum movimento mais brusco, às vezes eu até saía aos pulos assustado. Caminhava abatido, quase desmoronando, embora algo no seu olhar transparecesse certa firmeza.

A partir desse dia em que chegou destrambelhado, passou a frequentar esta casa regularmente, e ele não era o único. Enquanto eu deixo as minhas marcas de arranhão nos móveis, ele deixava as marcas dele nas portas e muros, pois também não lhe faltava ousadia e habilidade para desenhar. Era daí de onde vinha cada gota de tinta notável nos seus trajes. Estava sempre em trânsito. Eu o entendia bem, não aguento ficar quieto e nesta situação de rua também já estive. Ele carregava consigo esta facilidade em desenhar novas chegadas. Ah! Quase me esqueci da sua pasta de folhas rabiscadas. Amarela, assim como a sua pele. Há quem defenda que isso é consequência do seu fígado fraco por causa do longo período de uso do álcool e do crack. O que não se perguntaram foi se essa vida amarelada já não o acompanhava desde antes. 
Assim como o seu nome era ao avesso, ele conseguia também desvirar o que parecia não ter outro jeito. Fazia do amarelo uma obra de arte para muitos: aqueles que de arte só entendiam a vida. Coloria o branco chato da burocracia. Eu não te disse antes, mas ele não chegou aqui por acaso. Minha casa também é conhecida por ser um serviço de saúde mental, especialmente para usuários de álcool e outras drogas e, assim como ele, muitos outros chegavam diariamente. Hoje eu gosto disso, pois eles costumam cuidar de mim. Admito que no início eram quase cem pessoas que chegavam aqui diariamente e me assustavam tanto que eu tinha medo de descer do telhado.

Três vezes por semana ele frequentava este mesmo espaço no qual eu estava todos os dias. Assim como ele, tinha gente que aparecia só pela manhã, gente que aparecia só pela tarde, gente que aparecia todo dia manhã e tarde. Numa dessas manhãs desimportantes, uma garota chegou. Guardou a bolsa no armário e foi para o pátio dar bom dia para quem lá estivesse. $\mathrm{O}$ pátio era retangular, seus arredores formavam um "U" com o seu telhado e, para fechar o retângulo, tinha um grande muro branco. Eu circulava por todo espaço, de cima a baixo, mas a garota entrou no pátio pelo canto esquerdo e foi seguindo em direção ao canto superior esquerdo, canto superior direito, centro e voltou para o canto direito de onde tinha entrado. Neste canto havia cerca de cinco homens sentados no chão, aqui eles são conhecidos como "usuários de álcool”, haviam acabado de chegar e estavam por ali atualizando a conversa.

"Bom dia, bom dia, bom dia" - por algum motivo a garota sempre repetia três vezes. Por ali eu circulava e vi quando ela apertou a mão dos homens. Acho que ela perguntou como estavam e saiu para cumprimentar outras pessoas. Ao seguir para o mesmo canto esquerdo de onde ela entrou, passou por ele. Sentado, mãos passando pelos joelhos abraçando-os, cabeça inclinada, cabelo partido ao meio, longo até quase os ombros, preso atrás. Chift! Chift! (se coçando). Olhou para ele ao passar, ele olhou para ela e antes de desaparecer do seu campo de visão, soltou em tom desaforado: "Só fala com eles, é? Ontem você esteve aqui e não falou comigo. Todo o dia está por aqui e não fala comigo". Surpresa: "Oxente! [em sotaque baiano]. Não me lembro de ter te visto outro dia. Qual o seu nome?". Estendeu as mãos esperando um aperto de volta.

Todos os dias ali estávamos e ela nunca o tinha visto. Em relação a mim não posso dizer o mesmo, já fui salvo em momentos de correria porque ela conseguiu desviar de mim a tempo. Tou! (objeto cai no chão). Ops! Derrubei um vaso!

A partir de então, eles não deixaram de se ver. Das três vezes por semana que ele aqui estava, duas vezes coincidiam com os dias que ela também estava. De cima do telhado ou do pátio, conseguia vê-los conversando sempre. 
Semana atrás de semana e o papo era certo. Tiveram algum tempo para se conhecerem. A boca de um mexia mais que a da outra, mas conversavam. A cada dia uma atualização, construção de novo hábitos, reconstrução de novas perspectivas de vida. Desejos outros atravessavam a dupla que sentava no canto do álcool, no dominó, no vão da entrada da casa, no canto do fumo e na mesa durante o almoço enquanto jogavam farinha na marmita com feijão e arroz. Assim, a guria tomou conhecimento de que ele era órfão de pai e de mãe, compartilhava a vida com sua companheira com quem dormia nas ruas. Teve acesso ao nome de registro, embora o registro mesmo não houvesse ainda. Percebi que franziram a testa quando o nome saiu pela boca, seu apelido era muito mais singular e interessante.

Às vezes conseguia ouvir a garota informando-o sobre cursos técnicos, oficinas de alfabetização, editais de desenho e ouvi até sobre um encontro de grafiteiros. Ele não sabia ler, mas estava quase lá. Estava frequentando a oficina da tarde de alfabetização. Ele tinha muita vontade de oportunidades, quando elas apareciam, soltava o seu sorriso 'banguelo' cheio de graça. Às vezes eu percebia que tinham vergonha de rir por causa da falta de dentes, e isso eu nunca entendi porque ali a falta era muito mais comum do que o cheiro da planta que me nomeia. "Maconha*, desça daí!”.

Ele ainda tinha a rua como a sua casa quando começou a fazer um curso técnico pela promessa de um trabalho ao final. A garota, empolgada com tudo aquilo, puxou uma atividade que me deixou agitado, e assim como eu, as pessoas que ali estavam também ficaram. Eu sabia que era uma quarta porque havia um grupo de pessoas que só iam naquele dia e uma ou outra dessa gente costumava tirar fotos de mim. Primeiro, lá do telhado, vi que eles ficaram quietinhos olhando todos para uma tela que emitia sons e imagens. Depois, começaram a conversar, conversar, conversar, até que de repente surgiu um saco cheio de latas e potes. Miaaau! Tive muita vontade de rasgá-lo. Eles começaram a pegar o material e a pintar as paredes. Ele ficou ali no cantinho, concentrado, olhando para um papel e fazendo algo bem grande e colorido na parede. A garota, menos tranquila, estava de lá para cá conversando com um e com outro. Ao fim do dia, olhando para o seu desenho, ele e ela se emocionaram. Parecia que eles perguntavam para o mundo: será que haveria chances de fazer isso pelos muros afora profissionalmente?

Plaft! (pulo) Ainda bem que eu sempre caio em pé! Sei que o tempo passou bem passado. Foi o suficiente para a oficina de alfabetização e o curso técnico serem concluídos. Ao

\footnotetext{
* Maconha era um gato que foi adotado pelos usuários do CAPS. Nasceu de uma gatinha de outro serviço e foi para lá ainda bebê. Quando chegou, ficava só em cima do telhado, assustado. À medida que foi crescendo, foi descendo para o pátio, circulando, até que passou a se sentir à vontade a ponto de dormir nos sofás e cadeiras todo solto.
} 
fim, ele não conseguiu o trabalho prometido, novos muros não apareceram e saber ler ainda não pagava conta. Com isso, ele teve o que chamam por aqui de "recaída". Voltou a beber e a usar crack com maior frequência, chegava aqui em casa com uma cara de quem não dormiu, às vezes ainda chegava meio tonto, assim como no seu primeiro dia aqui. A garota começou a ficar um pouco abalada, mas soube esconder, é afeita a esconderijos. Ela tinha escutado uma vez que alguém precisava estar bem para apoiar quem não estava. Percebi que ela tentava argumentar contra a desesperança e a favor dos serviços que poderiam ajudá-lo - o que para ela era uma tarefa difícil, concordava com muito do que ele dizia. "Eles prometem, prometem e não cumprem! Já tem vários meses que eu espero me chamarem para fazer aquele serviço. Limpei o espaço lá e até hoje o dinheiro não saiu!”. Várias vezes ela ouviu outras pessoas de lá dizendo para ele "agora vai!", mas não ia. Não diziam com o intuito de iludi-lo, as outras pessoas também achavam que dava para ir.

Ele foi aparecendo cada dia mais cabisbaixo, ressaltando mais as faltas, chegou um momento em que achei que lhe faltava até a vida. Neste dia fiquei mais próximo, ganhei até um carinho nos meus pelos. Mmmmm! (suspiro de prazer). A situação chegou a um ponto que todos decidiram que ele moraria ali por um tempo, não mais que duas semanas. Ah! Pulei e corri de alegria. Seria mais um companheiro, agora durante o dia e a noite. Nesses dias, reparei que ele recebeu mais atenção, ouve uma grande investida em fazer com que todos pudessem acreditar de novo que aquela e as outras casas poderiam funcionar como diziam que funcionava. Ele foi largando a apatia e ganhando mais a sua cor amarelada. Os papéis mais uma vez se libertavam da brancura. Transformava o nada, que era o tudo, em alguma coisa. Entre desenhos, currículos e noites bem dormidas - a cama não lhe era íntima, mas era um aconchego só -, antes mesmo dos seus últimos dias lá em casa, surgiu-lhe uma proposta. Um emprego que trabalhava muito e ganhava pouco, exatamente como costuma ser. Que felicidade. Tum-tumtum-tum-tum! (coração batendo acelerado). Aí era só um pulo como o meu para conseguir a casa. E conseguiram! Pequena e periférica como costuma ser. Uhuuu! Gritaram. Até eu soltei o meu miaaaauuu! Tudo estava nos conformes: voltou a desenhar, reduziu o consumo, conseguiu o emprego, tinha uma casa com telhado, paredes e ainda vinha nos visitar - com uma frequência menor, é claro.

O tempo passou bem passado mais uma vez e ele apareceu com uma cara de quem comeu azedo que há muito não víamos. Trouxe uma preocupação. Primeiro para a garota, depois para os outros. Seu salário estava atrasado e o dono da casa o pressionava pelo dinheiro do aluguel. As pessoas tentaram resolver a questão naquele dia, mas a verdade é que eles pouco podiam fazer. Deram a ele algumas orientações e combinaram de conversar de novo sobre 
novas estratégias na sua próxima vinda caso o problema não tivesse dissolvido. No dia seguinte, veio a notícia da solução anunciada pela tela que emitia som e imagens. Sniff, sniff! (choro) Ouvi. "Usuário de droga morto a facadas". Ao sair daqui de casa, foi para a sua, o dono pediu o dinheiro do aluguel, ele tentou explicar que o salário estava atrasado, mas que seu chefe havia prometido que sairia logo. Mentira, seu drogado/ eu estou sem usar, me respeite! Não sou mentiroso!/ pague o meu aluguel, quer me enganar?/ senhor, se acalme. Assim que eu receber, trarei o dinheiro/ é agora ou agora! Você não vai gastar meu dinheiro com droga!/ senhor, eu estou sem usar! Não tenho dinheiro, veja! Aponta para o bolso. Antes que pudesse fazer mais qualquer defesa, o senhor foi tomado pela desconfiança que ele tinha desde o início ao descobrir que alugava a sua casa para um "usuário" sabe-se lá de quê. Desconfiança que não tinha com ele mesmo, como se nunca tivesse usado algo. A parede da casa que tinha a cor suja, a partir de então se coloriu com o vermelho avesso do amarelo.

\section{O condenável do costume}

A rua é um fator da vida das cidades, a rua tem alma! [...] A rua é generosa. O crime, o delírio, a miséria não os denuncia ela. A rua é a transformadora das línguas. [...] A rua continua, matando substantivos, transformando a significação dos termos, impondo aos dicionários as palavras que inventa, criando o calão que é o patrimônio clássico dos léxicons futuros. A rua resume para o animal civilizado todo o conforto humano. Dá-lhe luz, luxo, bem-estar, comodidade e até impressões selvagens no adejar das árvores e no trinar dos pássaros (João do Rio, 1907: 2).

Este não é um caso individual, mas a condução parece ter sido. As práticas clínicas orientadoras estavam voltadas para um empreender-se, para uma adequação do sujeito ao que se espera numa sociedade em que a exploração da força de trabalho é prioritária. Parece ter sido instaurado

um tipo de subjetividade que tende a desconhecer os estados intensivos e a orientar-se unicamente pela dimensão formal. Contribui para isso, o fato de que o mercado hoje converteu-se no principal - senão único - dispositivo de reconhecimento social. As subjetividades tendem a orientar-se cada vez mais em função deste reconhecimento e, portanto, das formas que se supõe valorizáveis, e cada vez menos em função da eficácia das formas enquanto veículos para as diferenças que se apresentam (ROLNIK, 1996: 02).

Este valor atribuído ao reconhecimento social, apresentando-o muitas vezes como a única opção para uma vida vivível, interfere na qualidade das relações que serão estabelecidas dentro de um serviço de saúde mental. O que importaria, portanto, seria a tentativa de instaurar uma reprodução de um modelo dado como de sucesso na vida de qualquer pessoa submetida aos cuidados desse serviço. Assim sendo, princípios básicos do cuidado em saúde já seriam negligenciados. Por exemplo, é possível visualizar o acolhimento como uma forma de encaixar 
o sujeito em alguma categoria predeterminada, o que já coloca em extinção a possibilidade de uma construção conjunta de projetos em um momento posterior.

Escrevemos e apagamos várias frases para dar continuidade a esta tentativa de desmoralização deste causo. Veja - ou sinta - são os afetos em trânsito. Não temos receios em dizer-lhes isto, pois "a escrita inventiva deve incluir não apenas os resultados finais que se mostraram favoráveis e representáveis, mas também o avesso da pesquisa, com as dificuldades e eventuais tensões e conflitos" (KASTRUP; PASSOS, 2013: 399). Este não é um caso individual, este é um causo de muitas vidas.

A morte faz parte do cotidiano do jovem negro periférico do Brasil, sendo ele usuário de drogas ou não. Diariamente é possível assistir às notícias de "jovem morto...", seguida de alguma comemoração por este ser sinal de um caminho para um país com menos violência, com mais segurança, desocupando as ruas e ocupando as almas privatizadas, mesma ideia de progresso por embranquecimento. "Porque um corpo preto morto é tipo os hit das parada/ Todo mundo vê, mas essa porra não diz nada" (EMICIDA, 2019). A cada 23 minutos um jovem negro é assassinado no Brasil e Aracaju é a sexta capital com maior taxa de homicídio por armas de fogo (WAISELFISZ, MAPA DA VIOLÊNCIA, 2016). Ou seja, apesar de a morte matada fazer parte do cotidiano de alguns sujeitos (muitas vezes classificados como elementos), a busca pela vida vivida habita e disputa o mesmo território.

Portanto, o desafio para nós colocado está em desenvolver uma argumentação que não condene os que condenaram, uma argumentação que se centre nas práticas, bibelôs dessa época (VEYNE, 2008) do empreender-se e autopoliciar-se. Se mencionamos acima que a intenção é habitar uma fronteira, não há como pisar num chão e apontar o outro como errado. O fato é que diariamente nossas conduções clínicas são interpeladas por este julgamento do que é certo e do que é errado e por vezes nos deparamos com a insistente apreciação da sujeição às normas instituídas. Não temos respostas, mas temos perguntas. Talvez seja essa a grande vantagem de uma clínica-política que aposta num exercício crítico: fazer perguntas.

Se falamos, então, de que necessitamos que algo seja válido como real, isso tem a ver com a suspeita de que falta algo ao que nos é dado como real. Como se o que nos dizem que é, o que nos dizem que existe, o que nos dizem que acontece, fosse uma espécie de realidade sem realidade, uma realidade, poderíamos dizer, des-realizada, como se estivesse inclinada a perder. E buscamos então algo assim como a realidade da realidade, esse ingrediente, ou essa dimensão, que faz com que algo ou alguém seja válido como real, que nos dê certa sensação de realidade (LARROSA, 2014: 108).

O que é mesmo o condenável, intolerável? Passar os dias rabiscando papéis e paredes? Ofertar muito pouco? Ter-se muito pouco o que ofertar? Ofertar a vida do homem empreendedor como projeto clínico? Naturalizar as precárias condições de moradia? Escolher 
morar nas ruas? Beber álcool e usar crack? Assim como o artista visual, "o caminhante transforma em outra coisa cada significante espacial" (CERTAU, 1998: 178). Este caminhante teve a vida interrompida quando se adequou/sujeitou. É esta adequação que chamamos de vida? Na adequação tem a morte, o trágico?

A arte é o campo privilegiado de enfrentamento do trágico (ROLNIK, 1996: 02).

E o sentimento de irrealidade, esse que faz com que a pessoa sucumba ou não se sinta viver quando já nada 'se torna real', está muito ligado ao sentimento de certa desvitalização da vida, a esse sentimento que nos faz dizer que esta vida não é vida, ou que a vida está em outra parte. Se isso nos acontece não é porque não estamos vivos, mas sim porque vivemos uma vida desvitalizada, uma vida à qual falta vida. E o que buscamos é algo assim como a vida da vida, uma vida que esteja cheia de vida (LARROSA, 2014: 107).

Será essa adequação um "afã por resolver imediatamente e de modo simplificado problemas de tamanha complexidade" (LANCETTI, 2015: 30)? Uma de suas formas de manifestar é "em cada cuidador e terapeuta que imagina salvar a vida das pessoas, que pelas razões mais complexas está habitando as bocadas e zonas de uso ou simplesmente de pessoas que procuram ajuda" (LANCETTI, 2015: 31). Antonio Lancetti (2015) apresenta a "contrafissura", esta sede em salvar vidas quase que numa lógica messiânica. Existem desterritorializações que são mortais. A crise pode ser mortal. Tirar uma pessoa em situação de rua da rua pode ser mortal. Praticar uma clínica que se faz crítica-política gera uma atenção para não encaixar as pessoas em fôrmas nas quais elas não cabem. Aqui novamente a estética encontra a clínica, artistando-a: um movimento de ir dando forma, experienciando em ato a desnaturalização das formas dadas.

A atuação é terapêutica, no sentido de atuar como "vetores de existencialização" quando, ao invés de uma busca constante pela adequação, foca no processo de criação de novos territórios. Portanto, quando tem "essa função de inserção no mundo da coletividade; de rompimento do isolamento que caracteriza a vivência subjetiva contemporânea" (RAUTER, 2000: 268) e proporciona o tornar-se ativo no mundo em que se vive.

Assim, a clínica a qual arriscamos colocar em prática questiona as formas dadas de uma realidade. Este é o sintoma desta clínica: a naturalização de uma realidade, fazendo dela um caso. Portanto, apostamos em "uma clínica comprometida em remexer as formas de estar no mundo, fazendo-as sempre potencializadoras de vida, produtoras de uma nova saúde" (PAULON, 2004: 269). O modo de entender e operar clínica, aqui, nada tem a ver com uma ocupação da "correção de sentidos" (PAULON, 2004: 267), com foco e culpabilização no 
indivíduo, nem tampouco tem a ver com "fabricar indivíduo" (BAPTISTA, 2000). A clínica na qual apostamos não se distancia da política.

A interface entre a clínica e a política se dá "porque aí nos encontramos com modos de produção, modos de subjetivação e não mais sujeitos, modos de experimentação/construção e não mais interpretação da realidade, modos de criação de si e do mundo" (BARROS e PASSOS, 2004:166) Portanto, temos em vista uma clínica da raiz etimológica do Clinamem com um significado de inclinação e desvio, o que nos abre a possibilidade de intercessão (PAULON, 2004). Dessa forma, é possível arriscar uma clínica "das passagens corporais, clínica da experimentação" (MACHADO et al., 2012: 162), artesanal e singular. "A vida é a experiência da vida, nossa forma singular de vivê-la. Por isso, colocar a relação educativa sob a tutela da experiência (e não da técnica, por exemplo, ou da prática) não é outra coisa que enfatizar sua implicação com a vida, sua vitalidade. Mas como? E sobretudo de que outro modo?" (LARROSA, 2014: 74).

Nossa aposta: a rua como o espaço suprassumo da multiplicidade, como um campo privilegiado de habitação do que se faz distinto do uno, embora ainda esteja vinculado a ele. A rua é habitada por todos nós, ainda que tenhamos experiências distintas. Aliás, não haveria outro modo de ser que não fosse distinto. A partir de tal aposta, é inerente pensar em modos de cuidado que prezem pela singularidade dos sujeitos, estejam eles em situação de rua ou não. Para tanto, faz-se necessário apreciar uma qualidade de presença, ou seja, é muito mais importante que saibamos exercitar uma abertura ao encontro ao estarmos com alguém que procura por um cuidado em saúde. Desta maneira, é possível entrar em contato com o que de fato faz sentido para este alguém e, a partir disto, elaborar o que seriam ações de promoção em saúde neste contexto.

É preciso andar mais à deriva, deixar-se seguir sem rumo no intuito de carregar menos certezas acerca do caminho que deve ser feito e aproveitar o percurso que será feito enquanto se segue. É preciso disposição para entrar em contato com o desconhecido e todas as suas possibilidades. Qual o percurso possível, portanto, para outros amar-elos, visando como primordial a experiência de ampliação da vida? Ensaiemos, cartografemos, mesmo que sejam regiões ainda por vir (DELEUZE; GUATTARI, 1995: 19).

Co(n)tidianos. Acompanhar labaredas do cotidiano do viver as e nas ruas, fazendo arder o real do humano das grades de proteção. Encontrar vidas da rua, encontrar vida na rua. Encontro ardente que, ao tocar o solo das coisas dadas/banais, faz deste mesmo chão propagação de fagulhas de sentidos e sensações, bem ali onde se imaginam imagens como a do gato que narra aqui essa história. 
Desde Goethe e Baudelaire, entendemos o sentido constitutivo da imaginação, sua capacidade de realização, sua intrínseca potência de realismo que a distingue, por exemplo, da fantasia ou da frivolidade. É o que fazia Goethe dizer: 'A Arte é o meio mais seguro tanto de alienarse do mundo como de penetrar nele' (DIDI-HUBERMAN, 2012: 208).

O pulo do gato ${ }^{6}$ : instalar um dispositivo artístico-narrativo-imagético em que pudemos desaparecer para dar expressão, língua e corpo ao cotidiano de vidas que se viram enredadas em narrativas oficiais (sociais, acadêmicas, especialistas), codificadas/coisificadas como "usuários de drogas" e/ou como “caso clínico". Imaginar o inimaginável: a humanidade dessas vidas por meio dos olhos de um gato, inumano. Com o verbo imaginar da esperança feminista ${ }^{7}$ desaprendemos: "para conhecer, é preciso imaginar”. É preciso arriscar algo trágico com o conhecimento: nos aproximar", nos desfazer de nossos velhos contratos de 'neutralidade' e distanciamento. Fazer a vida falar em suas miudezas, incertezas, descabimentos, encontros, desencontros, intensidades. Um gato que se relaciona com os demais seres por meio do pelo, pele do mundo. Pelo não governado pelo juízo, mas pela qualidade dos encontros. Um gato que acompanha, que é co-irmão desse outro existente que precisa, tal como ele, circular em liberdade, e que, por acaso, encontra, naquele espaço terapêutico, um acolhimento, uma hesitação às grades e aos donos da vida de outrem. Carícias no pelo-pele de um bom encontro, como também perplexidade em face do que humanos são capazes de fazer com outros humanos: transformá-los em corpos-coisa matáveis, com rosto/alma de drogado, filho da rua (e haverá sempre um dono para lembrá-lo de que não pode ser dono de si). Esse rosto/alma/identidade, o gato desconhece. E talvez o ensaio de liberdade (da vida narrada pelo pelo-pulo do gato, cria da rua) esteja justamente em não se adequar a essa política de rostidade. Adequar-se a ela sempre matará de uma maneira ou de outra. Não se adequar a ela talvez seja o charme que o gato reconhece nesse irmão de vida.

\section{Referências}

AGAMBEN, Giorgio. Infância e história: destruição da experiência e origem da história. Trad. Henrique Burigo. Belo Horizonte: Editora UFMG, 2005.

ANGELI, A. FONSECA, T. Trajetos poéticos por entre a clínica e as artes. Cadernos de Subjetividade / Núcleo de Estudos e Pesquisas da Subjetividade do Programa de Estudos Pós-Graduados em Psicologia Clínica da PUC-SP -vi, n.1 (1993). 2012.

BAPTISTA, Luis Antônio. A fábrica de interiores. A formação psi em questão. Niterói: Eduff, 2000.

BAPTISTA, Luis Antônio. Noturnos Urbanos: interpelações da literatura para uma ética da pesquisa. Estudos e pesquisas em psicologia. UERJ. Ano 10, nº1. 2010. p. 103-117. 
BARROS, Manoel de. O livro das ignorãças / Manoel de Barros. - Rio de Janeiro : Alfaguara, 2016.

BARROS, Regina B; PASSOS, Eduardo. Clínica, política e as modulações do capitalismo. Lugar Comum nº19-20, pp:159-171. Rede Universidade Nômade. $1^{\text {a }}$ edição, 2004.

BLANCHOT, Maurice. O livro por vir. Tradução Leyla Perrone-Moisés. - São Paulo: Martins Fontes, 2005.

BLANCHOT, Maurice. A conversa infinita: a experiência limite. Tradução de João Moura Jr. São Paulo: Escuta, 2007.

CERTEAU, Michel de. A invenção do cotidiano: as artes do fazer. $3^{\circ}$ edição. Editora Vozes. Petrópolis. 1998.

CORAZZA, Sandra. Artistagens: filosofia da diferença e educação. Editora Autêntica. 2006.

COUTO, Mia. Estórias abensonhadas. Editorial Caminho. 1994.

DELEUZE, Gilles. Conversações: 1972 - 1990. Rio de Janeiro: Editora 34, 1997.

DELEUZE; GUATTARI. Mil platôs: capitalismo e esquizofrenia, vol. 1. Rio de Janeiro, Ed. 34: 1995.

EMICIDA. Ismalia. Álbum amarElo.. Compositores: Aphonsus De Guimaraes / Daniel Conti Do Nascimento. Letra de Ismália.(C) Warner Chappell Music, Inc. 2019.

DIDI-HUBERMAN, Georges. Quando as imagens tocam o real. Revista Pós, Belo Horizonte, vol. 2 - n.4, nov. 2012. p. 204-219.

KASTRUP, Virginia. PASSOS, Eduardo. Sobre a validação da pesquisa cartográfica: acesso à experiência, consistência e produção de efeitos. Fractal, Rev. Psicol., v. 25 - n. 2, Maio/Ago. 2013. p. 391-414.

LANCETTI, A. Contrafissura e plasticidade psíquica. São Paulo: Hucitec, 2015.

LARROSA, J. Tremores: escritos sobre a experiência. Tradução Cristina Antunes, João Wanderley Geraldi. $1^{\text {o }}$ edição. Belo Horizonte: Autêntica Editora, 2014.

MACHADO, Dagoberto. VASCONCELOS, Michele. RESENDE, Aldo. O corpo como fio condutor para ampliação da clínica. P o lis e Psique, Vol.2, N ú m e ro T e mático, 201 2. p. 147-170.

PASSOS, Eduardo; BARROS, Regina. Por uma política da narratividade. In: Pistas do método da cartografia: Pesquisa-intervenção e produção de subjetividade / orgs. Eduardo Passos, Virgínia Kastrup e Liliana da Escóssia. - Porto Alegre: Sulina, 2015. p.150 171.

PASSOS, Eduardo; KASTRUP, Virgínia. Cartografar é traçar um plano comum. Fractal, Rev. Psicol., v. 25 - n. 2, p. 263-280, Maio/Ago. 2013.

PAULON, Simone. Clínica Ampliada: que(m) demanda ampliações? In: SOUSA, Edson; FONSECA, Tânia Galli; ELGELMAN, Selda (Orgs.). Corpo, Arte e Clínica. Para não ficar de mãos vazias. Porto Alegre: Editora da UFGRS, 2004. P. 259-273.

PELBART, Peter. O corpo, a vida, a morte. In: PASSETTI, Edson. (org.). Kafka, Foucault: sem medos. São Paulo: Ateliê Editorial, 2004. p. 139-156.

RAUTER, Cristina. Oficinas para quê? Uma proposta ético-estético-política para oficinas terapêuticas. In: AMARANTE, Paulo (org). Ensaios: subjetividade, saúde mental, 
sociedade. Rio de Janeiro: Editora FIOCRUZ, 2000. Loucura \& Civilização, pp. 267277.

RIO, João do. A alma encantadora das ruas: crônicas. Secretaria Municipal de Cultura. Dep. Geral e Doc. e Inf. Cultural, divisão de editoração. Rio de Janeiro, 1995.

ROLNIK, Suely. Lygia Clark e o híbrido arte/clínica. Percurso - Revista de Psicanálise. Ano VIII, no $16: 43-48,1^{\circ}$ semestre de 1996. Departamento de Psicanálise, Instituto Sedes Sapientiae, São Paulo, 1996.

VEYNE, P. Como se escreve a história: Foucault revoluciona a história. Brasília: Universidade de Brasília, 2008.

WAISELFISZ, Julio Jacobo. Mapa da Violência 2016: homicídios por armas de fogo no Brasil. Flacso Brasil. 2016.

Jéssica Fernandes Pinto

Universidade Federal de Sergipe

E-mail: jessicafernandespinto@gmail.com;

Michele de Freitas Faria de Vasconcelos

Universidade Federal de Sergipe

E-mail: michelevasconcelos@hotmail.com.

\footnotetext{
${ }^{1}$ Utilizaremos a primeira pessoa do singular quando acharmos necessário para localizar a experiência de uma das autoras ou por questões de estilo.

${ }^{2}$ CAPS em que ambas autoras habitaram (e habitam), em épocas diferentes, nas funções de trabalhadoras de saúde mental, em espaços de gestão e atenção, estagiária de Psicologia, residente de Saúde Mental, supervisora de estágio em Psicologia Institucional.

${ }^{3}$ Frase dita por um personagem do filme brasileiro "A febre do rato" ao confraternizar com pessoas de sua comunidade. A película foi lançada em 2012, dirigida pelo diretor Cláudio Assis. Saliente-se que a expressão popular recifense que dá título ao filme é utilizada em alusão a pessoas que estariam fora de "controle", "fora de si”.

${ }^{4}$ Algo que se torna popular na internet - que viraliza.

${ }^{5}$ Diziam que precisavam dormir com um olho aberto e outro fechado porque a rua à noite não dorme, o perigo é sempre iminente.

${ }^{6}$ Agradecemos imensamente os pareceres da revista. Este parágrafo, ousadamente, descreve quase que literalmente algumas passagens de um deles.

7 Esperança Feminista, verbo Imaginar, com Débora Diniz e Ivone Gebara. https://www.youtube.com/watch?v=LklIbpPsd0g. Acessado em 17/11/2020.
} 